\title{
TLR4 rs41426344 increases susceptibility of rheumatoid arthritis (RA) and juvenile idiopathic arthritis (JIA) in a central south Chinese Han population
}

Yan Wang ${ }^{1,2,3}$, Lianghui Chen ${ }^{1,2,3}$, Fang $\mathrm{Li}^{1,2}$, Meihua Bao ${ }^{1,2}$, Jie Zeng ${ }^{1,2}$, Ju Xiang ${ }^{1,2}$, Huaiqing Luo ${ }^{1,2,3}$, Jianming $\mathrm{Li}^{1,4^{*}}$ and Liang Tang ${ }^{1,2^{*}}$

\begin{abstract}
Background: The aim of the study was to determine whether polymorphisms in toll-like receptor 4 (TLR4) confer susceptibility to rheumatoid arthritis (RA) and juvenile idiopathic arthritis (JIA) in a central south Chinese Han population.

Methods: Genotyping for six well studied polymorphisms (rs4986790, rs4986791, rs10759932, rs41426344, rs 11536889 and rs7873784) in TLR4 gene were conducted in 1074 unrelated patients with RA and 1692 healthy control subjects, as well as in 217 unrelated patients with JIA and 378 healthy control subjects using direct sequencing technique. Comparisons between cases and controls in alleles, genotypes and haplotypes were carried out using Fisher's exact test.

Results: Significant genetic associations were detected between the 3'UTR rs41426344C and RA ( $p<0.001, p_{\text {adj }}<0.001$, $\mathrm{OR}=2.24)$ and JIA $\left(p<0.001, p_{\text {adj }}<0.001, \mathrm{OR}=2.05\right)$. In addition, rs4986790G was found to be significantly associated with the susceptibility for RA $\left(p=0.005, p_{\text {adj }}=0.03, \mathrm{OR}=3.43\right)$, but not for JIA $\left(p=0.06, p_{\text {adj }}=0.36, \mathrm{OR}=2.65\right)$.

Furthermore, significant increasing in the distributions of haplotypes $\mathrm{H} 4$ and $\mathrm{H} 10$ in $\mathrm{RA}$ ( $H 4$ : $p=0.001, \mathrm{OR}=1.13 ; \mathrm{H10}$ : $p=0.001, \mathrm{OR}=1.15)$ and JIA (H4: $p=0.04, \mathrm{OR}=2.06 ; \mathrm{H10}: p=0.02, \mathrm{OR}=2.47)$ were also found. Moreover, the frequency of rs41426344C significantly increased in RF-positive and anti-CCP positive subjects both in $R A\left(\mathrm{RF}^{+}: p<0.0001, \mathrm{OR}=2\right.$. 33; anti-CCP $\left.{ }^{+}: p=0.008, \mathrm{OR}=2.79\right)$ and JIA $\left(\mathrm{RF}^{+}: p=0.02, \mathrm{OR}=2.91\right.$; anti-CCP$\left.{ }^{+}: p=0.02, \mathrm{OR}=2.78\right)$.
\end{abstract}

Conclusions: Our study suggested that rs41426344 and rs4986790 of TLR4 might contribute to RA, and rs41426344 might contribute to JIA pathogenesis in central south Chinese Han population.

Keywords: Genetic association, Toll like receptors 4 (TLR4), Rheumatoid arthritis (RA), Juvenile idiopathic arthritis (JIA), Chinese Han population

\section{Background}

Rheumatoid arthritis (RA) is an autoimmune disease characterized by progressive particular damage caused by inflammatory cells and synoviocytes and was thought to be caused by complex interaction of multiple susceptibility genes and environmental factors [1]. It affects

\footnotetext{
*Correspondence: tlcool318@163.com

'Department of Human Anatomy, Histology and Embryology, Institute of Neuroscience, Changsha Medical University, No. 1501 Lei Feng Road, Wangcheng District, Changsha City, Hunan Province 410219, People's Republic of China

Full list of author information is available at the end of the article
}

approximately $0.32 \%$ Chinese Han population and $1 \%$ Caucasian respectively. Juvenile idiopathic arthritis (JIA) refers to a group of chronic childhood arthropathies of unknown aetiology [2]. Chronic arthritis is a common feature of RA and JIA. Familiar and twins studies have provided robust evidence for the role of genetic factors in these diseases $[3,4]$.

Toll-like receptors (TLRs) play important roles in the recognition of inflammatory diseases caused by invading microorganisms. They have been also increasingly suggested to have important roles in RA and JIA $[5,6]$. 
There are 13 structurally unique members identified in TLRs family. Toll-like receptor 4 (TLR4), one of the important member of TLRs, plays a key role in the process of the innate immune response, and activates the nuclear factor- $\mathrm{kB}(\mathrm{NF}-\mathrm{kB})$ signaling pathway by binding to lipopolysaccharide (LPS), which was identified to be an important mechanism in the development of rheumatic diseases [7-11].

The TLR4 gene consisting of three exons is located on chromosome 9q32-33 [12]. Previous studies have reported that some polymorphisms in the TLR4 coding/ non-coding region, in particular Asp299Gly polymorphism, are associated with a blunted receptor activity and a subsequently diminished inflammatory response in humans [13-16]. Furthermore, variants in the TLR4 were also reported to be associated with lymphoid tissue lymphoma [17], Hodgkin lymphoma [17], cancer [18] and ischemic cerebrovascular disease [19]. Surprisingly, relatively few genetic studies reported significant associations of polymorphisms in TLR4 with RA and JIA susceptibility. Most studies have focused on the correlation between two well known TLR4 polymorphisms (Asp299Gly and Thr399Ile) and RA and JIA, while inconclusive or contradictory results were observed [20, 21]. To our knowledge, only three studies with relatively small sample size have investigated the association between variants in the TLR4 and RA in Chinese Han population [22-24], and negative result was also reported [23, 24]. In addition, no research conducted on the association between TLR4 polymorphisms and JIA in central Chinese Han population was found. Thus, the role of TLR4 in RA and JIA in central Chinese Han population remains unclear.

In present study, we aimed to examine the possible associations of TLR4 polymorphisms with auto-antibody levels in RA and JIA susceptibility in a central south Chinese Han population.

\section{Methods \\ Sample collection}

The study was approved by the Ethical Committee at Changsha Medical University (EC/14/013, 06/11/2014). Written, informed consents for genetic analysis were obtained from all subjects or their guardians. A total of 1074 unrelated patients (Female/Male: 842/232; age: $41.7 \pm 11.6$ years) who met the American College of Rheumatology (The American Rheumatism Association) 1987 revised criteria for RA [25] and 217 unrelated patients (boy/girl: 178/39; age: $6.3 \pm 3.1$ years) who fulfilled the EULAR JIA criteria were recruited from the first affiliated hospital, Changsha Medical University. Rheumatoid factor (RF) and anti-cyclic citrullinated peptide (anti-CCP) status were determined for all the patients. The erythrocyte sedimentation rate (ESR) was tested by Westergren method. The auto-antibody levels were detected by Enzyme-linked immunosorbent assay (ELISA). In addition, 1692 unrelated control subjects without the history of RA and 378 unrelated control subjects without the history of JIA (matched for ethnicity, gender and age) for this study were also enrolled. The control subjects were healthy individuals who took the health examination in the first affiliated hospital, Changsha Medical University. All participants were Chinese Han population in origin.

\section{Genotyping}

A combination of 6 well-studied informative TLR4 SNPs (Two functional variants [rs4986790 (Asp299Gly) and rs4986791 (Thr399Ile) in exon 3, one variant (rs10759932) in 5'UTR and three variants (rs41426344, rs11536889 and rs7873784) in 3'UTR were genotyped in RA, JIA and healthy controls. Genomic DNA was extracted from peripheral leukocytes using the standard phenol-chloroform method [26]. The multiplex PCR was carried out on the ABI Veriti Thermal Cycler (Applied Biosystems, Foster City, CA). Genotyping was conducted using direct sequencing by the ABI 3730XL DNA Sequencer (Applied Biosystems, Foster City, CA). The PCR primers and sequencing probes were shown in Additional file 1: Table S1.

\section{Statistical analysis}

Hardy-Weinberg equilibrium (HWE) was tested in the cases and controls using a classic chi-square test with $1^{\circ}$ of freedom. The statistical analysis was performed using SHESIS (http://analysis.bio-x.cn/SHEsisMain.htm). Individual analyses of associations between TLR4 polymorphisms and RA and JIA, as well as clinical features were performed by comparing alleles and genotypes in cases and controls using Fisher's exact test. The corresponding ORs and 95\% confidence intervals (CI) were assessed using a standard logistic regression analysis. Bonferroni correction was applied to adjust the $p$ value $\left(P_{\text {adj }}\right)$ in multiple comparisons. Analysis of haplotype diversity was performed using the expectation-maximization algorithm (EM). Specific $P$ values and ORs and 95\% confidence intervals $(\mathrm{CI})$ were obtained by comparing each haplotype with the more common haplotype in the population using Fisher's exact test. Statistical significance was set at $p<0.05$.

\section{Results}

Clinical features such as erythrocyte sedimentation rate (ESR), C-reactive protein (CRP), IgA, IgG, IgM were shown in Table 1. For JIA, the patients can be classified into five subtypes (systemic JIA, polyarticular $\left(\mathrm{RF}^{+}\right.$and $\mathrm{RF}^{-}$) JIA, pauciarticular JIA, psoriatic JIA and other JIA). There were $21(9.6 \%), 52(23.7 \%)\left(\mathrm{RF}^{+}: 15(6.9 \%)\right.$; $\mathrm{RF}^{-}$: 37 (16.8\%)), 111 (51.2\%), 28 (12.9\%) and 5 (2.3\%) separately for each subtype. 
Table 1 Clinical characteristics of RA and JIA patients and heathy controls

\begin{tabular}{|c|c|c|c|c|c|c|}
\hline Clinical characteristics & RA (Mean $\pm S D)$ & Control (Mean \pm SD) & $p$ & $J \mid A($ Mean $\pm S D)$ & Control (Mean \pm SD) & $p$ \\
\hline Sex ratio (Female/Male) & $3.63(842 / 232)$ & $3.47(1314 / 378)$ & 0.17 & $4.56(178 / 39)$ & $4.72(312 / 66)$ & 0.89 \\
\hline Age (years) & $41.7 \pm 11.6$ & $39.6 \pm 13.2$ & 0.75 & $6.3 \pm 3.1$ & $6.7 \pm 2.5$ & 0.75 \\
\hline Onset age, years & $49.5 \pm 7.9$ & - & - & $7.5 \pm 4.9$ & - & - \\
\hline Bone erosions n (\%) & $421(39.1 \%)$ & - & - & $46(21.3 \%)$ & - & - \\
\hline Shared epitope & $467(43.5 \%)$ & - & - & 79 (36.4\%) & - & - \\
\hline DAS28 & $4.7 \pm 1.3$ & - & - & $3.4 \pm 1.1$ & - & - \\
\hline ESR (mm/h) (0-10 mm/h) & $33.2 \pm 12.5$ & $4.5 \pm 2.2$ & $<0.001$ & $34.5 \pm 19.3$ & $4.3 \pm 2.4$ & $<0.001$ \\
\hline CRP (mg/l) $(0.8-8$ mg/l) & $25.8 \pm 12.2$ & $4.9 \pm 1.3$ & $<0.001$ & $19.3 \pm 37.5$ & $3.77 \pm 1.4$ & $<0.001$ \\
\hline lgA mg/mL (0.71-3.35 mg/mL) & $12.2 \pm 2.7$ & $2.88 \pm 1.4$ & $<0.001$ & $10.2 \pm 2.4$ & $2.59 \pm 1.7$ & $<0.001$ \\
\hline lgG mg/mL (7.6-16.6 mg/mL) & $45.7 \pm 5.4$ & $10.3 \pm 4.1$ & $<0.001$ & $29.6 \pm 5.1$ & $9.7 \pm 1.3$ & $<0.001$ \\
\hline $\operatorname{lgM} \mathrm{mg} / \mathrm{mL}(0.48-2.12 \mathrm{mg} / \mathrm{mL})$ & $6.6 \pm 1.3$ & $1.78 \pm 2.1$ & $<0.001$ & $5.4 \pm 1.7$ & $1.88 \pm 1.02$ & $<0.001$ \\
\hline $\mathrm{RF}^{+}, \%$ & $826(76.9 \%)$ & $0(0 \%)$ & & 37 (16.9\%) & $0(0 \%)$ & \\
\hline $\mathrm{CCP}^{+}, \%$ & $766(71.3 \%)$ & $0(0 \%)$ & & $33(15.4 \%)$ & $0(0 \%)$ & \\
\hline
\end{tabular}

Abbreviation: SD Standard Deviation, ESR erythrocyte sedimentation rate, $C R P$ C-reactive protein, $R F$ rheumatoid factor, JIA juvenile idiopathic arthritis, $R A$ Rheumatoid arthritis

Disease activity score 28(DAS28): a score for evaluation of RA activity by assessing the state of 28 joints; anti-CCP: anti-cyclic citrullinated peptide

\section{Single-locus association}

All variants in cases and controls were in HardyWeinberg equilibrium (HWE) $(p>0.05)$. Genotype data for the 6 TLR4 SNPs successfully typed in the central south Chinese Han population cases and controls were examined by single-marker analysis (Tables 2 and 3). Genotype analysis showed that the distribution of rs41426344 CC was significantly higher in RA and JIA patients compared with controls, even after the Bonferroni's correction (RA: $p<0.001, p_{\text {adj }}<0.001$, OR [CI95\%]: 3.75 [2.51-5.6]; JIA: $p=0.0002, p_{\text {adj }}=0.0006$, OR [CI95\%]: 4.79 [1.97-11.67]). The frequencies of rs41426344C in RA and JIA were 0.21 and 0.25 separately. Significant associations between rs41426344C and RA and JIA were observed in further allelic analysis (RA: $p<0.001, p_{\text {adj }}<0.001$, OR
[CI95\%]: 2.24 [1.76-2.85]; JIA: $p<0.001, p_{\text {adj }}<0.001$, OR [CI95\%]: 2.05 [1.52-2.77]).

The distribution of the rs4986790GA in RA cases was significantly higher than that in controls $(p<0.001$, $p_{\text {adj }}<0.001$, OR [C195\%]: 3.47 [2.06-5.87]). And allelic analysis of the RA cohort revealed that the frequency of the rs4986790G was significantly higher in patients (2\%) compared with controls $(0.06 \%)$ with an OR equal to 3.43 $\left(p=0.005, p_{\text {adj }}=0.03\right.$, OR [CI95\%]: 3.43 [1.39-8.45]), which indicated that $\mathrm{G}$ allele in rs4986790 might reveal a strong risk factor for RA in central south Chinese Han population.

No association was detected between other SNPs in the 3'UTR (rs11536889 and rs7873784) and 5'UTR (rs10759932) of the TLR4 gene and RA and JIA $(p>0.05)$.

Table 2 Allele distributions of TLR4 gene polymorphisms in RA, JIA and healthy controls

\begin{tabular}{|c|c|c|c|c|c|c|c|c|c|c|c|c|}
\hline \multirow[b]{2}{*}{ SNPS (MAF) } & \multirow[b]{2}{*}{ Region } & \multirow[b]{2}{*}{ Position } & \multicolumn{2}{|l|}{ RA } & \multirow[b]{2}{*}{$P$} & \multirow[b]{2}{*}{$P_{\text {adj }}^{a}$} & \multirow[b]{2}{*}{ OR $[95 \% \mathrm{Cl}]^{b}$} & \multicolumn{2}{|l|}{$J \mathrm{~A}$} & \multirow[b]{2}{*}{$P$} & \multirow[b]{2}{*}{$P_{\text {adj }}^{a}$} & \multirow[b]{2}{*}{ OR $[95 \% \mathrm{Cl}]^{\mathrm{b}}$} \\
\hline & & & $\begin{array}{l}\text { Case } \\
\text { (freq.) }\end{array}$ & $\begin{array}{l}\text { Control } \\
\text { (freq.) }\end{array}$ & & & & $\begin{array}{l}\text { Case } \\
\text { (freq.) }\end{array}$ & $\begin{array}{l}\text { Control } \\
\text { (freq.) }\end{array}$ & & & \\
\hline rs10759932(C) & 5'UTR & 27786349 & 0.32 & 0.29 & 0.37 & - & 1.10 [0.89-1.34] & 0.26 & 0.26 & 0.86 & - & $1.03[0.78-1.34]$ \\
\hline rs4986790 (G) & Exon 3 & 27796507 & 0.02 & 0.006 & 0.005 & 0.03 & $3.43[1.39-8.45]$ & 0.02 & 0.008 & 0.06 & - & $2.65[0.93-7.49]$ \\
\hline rs4986791 (T) & Exon 3 & 27796807 & 0.05 & 0.04 & 0.03 & 0.18 & 1.75 [1.09-2.82] & 0.07 & 0.05 & 0.12 & - & $1.46[0.90-2.37]$ \\
\hline rs41426344 (C) & 3'UTR & 27799138 & 0.21 & 0.13 & $<0.001$ & $<0.001$ & $2.24[1.76-2.85]$ & 0.25 & 0.14 & $<0.001$ & $<0.001$ & $2.05[1.52-2.77]$ \\
\hline rs11536889 (C) & $3^{\prime} U T R$ & 27799336 & 0.22 & 0.19 & 0.07 & - & $1.24[0.98-1.56]$ & 0.23 & 0.19 & 0.19 & - & $1.21[0.91-1.61]$ \\
\hline rs7873784 (C) & $3^{\prime} U T R$ & 27800141 & 0.15 & 0.12 & 0.03 & 0.18 & 1.35 [1.03-1.77] & 0.13 & 0.14 & 0.68 & - & $0.93[0.66-1.31]$ \\
\hline
\end{tabular}

Abbreviation: SNP, single nucleotide polymorphism, MAF minor allele frequency, OR odds ratio, 95\% CI 95\% confidence intervals, not calculated, RA Rheumatoid arthritis, JIA juvenile idiopathic arthritis, Freq frequency; $p_{\text {adj, }} p_{\text {adjusted }}$

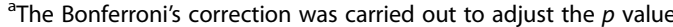

${ }^{\mathrm{b}} \mathrm{OR}$ and $95 \% \mathrm{Cl}$ are calculated for the minor allele of each SNP 
Table 3 Distribution of the genotypes of TLR4 gene polymorphisms in RA and JIA cases and controls

\begin{tabular}{|c|c|c|c|c|c|c|c|c|c|c|c|}
\hline SNPS & Genotype & Control no. & RA no. & OR [95\%Cl] & $p^{a}$ & $p_{\mathrm{adj}}^{\mathrm{b}}$ & Control no. & JIA no. & OR [95\%Cl] & $p^{a}$ & $p_{\mathrm{adj}}^{\mathrm{b}}$ \\
\hline \multirow[t]{3}{*}{ rs10759932 (C) } & $\pi$ & 844 & 498 & $0.87[0.74-1.01]$ & 0.07 & - & 204 & 125 & $1.16[0.83-1.62]$ & 0.39 & - \\
\hline & $\mathrm{CT}$ & 696 & 466 & 1.09 [0.94-1.28] & 0.24 & - & 151 & 73 & $0.76[0.54-1.08]$ & 0.13 & - \\
\hline & $\mathrm{CC}$ & 143 & 108 & $1.21[0.93-1.57]$ & 0.15 & - & 23 & 19 & $1.48[0.79-2.79]$ & 0.22 & - \\
\hline \multirow[t]{3}{*}{ rs4986790 (G) } & $\mathrm{AA}$ & 1671 & 1029 & $0.28[0.17-0.49]$ & $<0.001$ & $<0.001$ & 372 & 208 & $0.37[0.13-1.06]$ & 0.06 & - \\
\hline & GA & 21 & 45 & $3.47[2.06-5.87]$ & $<0.001$ & $<0.001$ & 6 & 9 & $2.68[0.94-7.64]$ & 0.06 & - \\
\hline & GG & 0 & 0 & - & - & - & 0 & 0 & - & - & - \\
\hline \multirow[t]{3}{*}{ rs4986791 (T) } & $\mathrm{CC}$ & 1590 & 986 & $0.72[0.53-0.96]$ & 0.03 & 0.09 & 399 & 186 & $0.58[0.35-0.97]$ & 0.04 & 0.12 \\
\hline & $C T$ & 100 & 85 & $1.37[1.01-1.84]$ & 0.04 & 0.12 & 39 & 30 & 1.65 [0.99-2.73] & 0.05 & - \\
\hline & $\pi$ & 2 & 3 & - & - & - & 0 & 1 & - & - & - \\
\hline \multirow[t]{3}{*}{ rs41426344 (C) } & GG & 1287 & 615 & $0.42[0.36-0.49]$ & $<0.001$ & $<0.001$ & 280 & 127 & $0.49[0.35-0.70]$ & $<0.001$ & $<0.001$ \\
\hline & GC & 369 & 378 & $1.94[1.64-2.31]$ & $<0.001$ & $<0.001$ & 91 & 72 & 1.57 [1.08-2.26] & 0.02 & 0.06 \\
\hline & $\mathrm{CC}$ & 36 & 81 & $3.75[2.51-5.6]$ & $<0.001$ & $<0.001$ & 7 & 18 & 4.79 [1.97-11.67] & 0.0002 & 0.0006 \\
\hline \multirow[t]{3}{*}{ rs11536889 (C) } & GG & 1113 & 647 & $0.79[0.67-0.92]$ & 0.003 & 0.009 & 242 & 133 & $0.89[0.63-1.26]$ & 0.51 & - \\
\hline & GC & 518 & 372 & $1.20[1.02-1.41]$ & 0.03 & 0.09 & 125 & 70 & $0.96[0.67-1.37]$ & 0.84 & - \\
\hline & $\mathrm{CC}$ & 60 & 54 & 1.44 [0.99-2.09] & 0.06 & - & 11 & 14 & $2.3[1.02-5.16]$ & 0.04 & 0.12 \\
\hline \multirow[t]{3}{*}{ rs7873784 (C) } & GG & 1308 & 790 & $0.81[0.68-0.97]$ & 0.02 & 0.06 & 278 & 165 & $1.14[0.78-1.68]$ & 0.50 & - \\
\hline & GC & 358 & 268 & 1.24 [1.03-1.48] & 0.02 & 0.06 & 96 & 48 & $0.83[0.56-1.23]$ & 0.37 & - \\
\hline & CC & 25 & 16 & 1.01 [0.54-1.89] & 1.00 & - & 4 & 4 & $1.76[0.43-7.09]$ & - & - \\
\hline
\end{tabular}

Abbreviation: SNP single nucleotide polymorphism, OR odds ratio, 95\% CI 95\% confidence intervals; -, not calculated, RA Rheumatoid arthritis, JIA juvenile idiopathic arthritis

${ }^{\text {a }} P$ value were calculated using Fisher's exact test

'The Bonferroni's correction was carried out to adjust the $P$ value

And no notable association was detected between both genotypes and alleles in rs4986790 and JIA $(p>0.05)$.

\section{Haplotype analysis}

Haplotypes were predicted for 6 SNPs using PLINK 1.09 (http://pngu.mgh.harvard.edu/ purcell/plink/). Ten haplotypes in RA and JIA separately with a frequency $>1 \%$ were predicted in both cases and controls accounting for $>90 \%$ of all the haplotypes. The haplotype $1(\mathrm{H} 1)$ (TACGGG) containing rs10759932T, rs4986790A, rs4986791C, rs41426344G, rs11536889G, rs7873784G was the most common haplotype with a frequency of approximately $43 \%$ in RA and $42 \%$ in JIA. However, no association was found between $\mathrm{H} 1$ and RA and JIA $(p>0.05)$. Additionally, we observed a marginally significant increase in the distribution of H4 (TGTCCG) and H10 (CGTCCG) in RA compared with that in the controls (H4: $p=0.001$, OR $[95 \% \mathrm{CI}]=1.13[0.77-1.26]$; H10: $p=0.001$, OR $[95 \% \mathrm{CI}]=1.15[1.02-1.56])$ (Table 4). Similar results were found in $\mathrm{H} 4$ and $\mathrm{H} 10$ in JIA and controls (TGTCCG: $p=0.04$, OR $[95 \% \mathrm{CI}]=2.06[1.01-4.21]$; H10: $p=0.02$, OR $[95 \% \mathrm{CI}]=2.47[1.11-5.49])($ Table 4$)$.

\section{Allelic/Genotypic distribution of RF and anti-CCP in RA and JIA}

Data were available on autoantibody levels including information on circulating RF and anti-CCP. Carriage of
rs41426344C significantly increased in RF-positive $\left(\mathrm{RF}^{+}\right.$vs. $\mathrm{RF}^{-}: 0.17$ vs. 0.08 ) and anti-CCP positive (anti-CCP ${ }^{+}$vs. anti-CCP ${ }^{-}: 0.15$ vs. 0.06$)$ subjects in $\mathrm{RA}\left(\mathrm{RF}^{+}: p<0.0001\right.$, OR $[95 \% \mathrm{CI}]=2.33[1.65-3.01]$; anti-CCP ${ }^{+}: p=0.008$, OR $[95 \% \mathrm{CI}]=2.79[1.28-6.11])$ and JIA $\left(\mathrm{RF}^{+}\right.$vs. $\mathrm{RF}^{-}: 0.19$ vs. 0.08 ; anti-CCP ${ }^{+}$vs. anti-CCP ${ }^{-}: 0.16$ vs. 0.05$)\left(\mathrm{RF}^{+}: p=0.02\right.$, OR $[95 \% \mathrm{CI}]=2.91$ [1.11-7.56]; anti-CCP ${ }^{+}: p=0.02$, OR $[95 \% \mathrm{CI}]=2.78[1.21-6.74])$ (Table 5). Allele and genotype frequencies were not different after stratification by antiCCP status for rs 4986790 that was shown to be associated with RA and JIA in our study (Table 5).

\section{Discussion}

In the current study, 1074 RA, 217 JIA and 2070 healthy controls were genotyped for six polymorphisms in the TLR4 gene that was previously reported to be associated with autoimmune diseases. The data showed that the frequencies of TLR4 rs4986790G in RA cases, as well as rs41426344C in JIA cases significantly increased than that in the controls, which was, to our knowledge, the first study to demonstrate associations between the two common polymorphisms and RA and JIA in central Chinese Han population using case-control design.

TLRs play important roles in both innate and adaptive immune responses that invading by microorganisms [27]. The chronic inflammation and the well-recognized interactions of TLRs with numerous endogenous ligands 
Table 4 Haplotype analysis of RA and JIA cases and the healthy controls in the TLR4 genes

\begin{tabular}{|c|c|c|c|c|c|c|c|}
\hline \multirow[t]{2}{*}{ NO. } & \multirow[t]{2}{*}{ haplotype $^{a}$} & \multicolumn{2}{|l|}{ RA } & \multirow[t]{2}{*}{ OR [95Cl\%], $P^{b}$} & \multicolumn{2}{|l|}{$J \mathrm{~A}$} & \multirow[t]{2}{*}{ OR [95C|\%], $P^{b}$} \\
\hline & & Control (freq.) & Case (freq.) & & Control (freq.) & Case (freq.) & \\
\hline $\mathrm{H} 1$ & TACG G G & 0.47 & 0.43 & $1.03[0.99-1.17], 0.29$ & 0.45 & 0.42 & $0.72[0.52-1.01], 0.06$ \\
\hline $\mathrm{H} 2$ & TACG GC & 0.06 & 0.12 & $1.07[0.83-1.33], 0.07$ & 0.06 & 0.10 & $1.74[0.95-3.21], 0.07$ \\
\hline H3 & TACG C G & 0.11 & 0.09 & $0.54[0.22-1.11], 0.13$ & 0.10 & 0.07 & $0.66[0.36-1.23], 0.19$ \\
\hline $\mathrm{H} 4$ & T G TC C G & 0.02 & 0.08 & $1.13[0.77-1.26], 0.001$ & 0.04 & 0.08 & $2.06[1.01-4.21] 0.04$ \\
\hline H5 & TACCCC & 0.003 & 0.01 & $1.09[0.76-1.45], 0.06$ & 0.003 & 0.006 & $1.75[0.11-2.86], 0.39$ \\
\hline H6 & $C A \subset G G G$ & 0.06 & 0.06 & $1.01[0.99-1.03], 0.89$ & 0.04 & 0.06 & $1.54[0.72-3.31], 0.26$ \\
\hline $\mathrm{H} 7$ & $C A C G C G$ & 0.01 & 0.02 & $1.10[0.98-1.24], 0.57$ & 0.02 & 0.02 & $0.87[0.26-2.93], 0.78$ \\
\hline H8 & $C A C G C C$ & 0.003 & 0.001 & $0.86[0.63-1.05], 0.69$ & 0.002 & 0.003 & $1.74[0.11-2.04], 0.54$ \\
\hline H9 & $C A \subset C G G$ & 0.14 & 0.11 & $0.98[0.97-0.99], 0.07$ & 0.15 & 0.11 & $0.70[0.42-1.16], 0.17$ \\
\hline $\mathrm{H} 10$ & $C G T C C G$ & 0.03 & 0.13 & $1.15[1.02-1.56], 0.001$ & 0.03 & 0.07 & $2.47[1.11-5.49], 0.02$ \\
\hline
\end{tabular}

Abbreviation: SNP single nucleotide polymorphism, OR odds ratio, 95\% CI 95\% confidence intervals; -, not calculated, RA Rheumatoid arthritis, JIA juvenile idiopathic arthritis, Freq frequency

${ }^{a}$ Haplotype structure of TLR4 for RA and JIA were rs4986790, rs4986791, rs10759932,rs41426344, rs11536889, rs7873784

${ }^{\mathrm{b}} P$ value were calculated using Fisher's exact test

have implicated this pathway in a number of disease states including RA and JIA $[27,28]$. As a member of TLRs, TLR4 has been considered to recognize not only the LPS component of gram-negative bacteria but also the mouse mammary tumor virus [29, 30]. In particular, TLR4 has been identified as an important part of investigation in understanding arthritides pathogenesis. It has been also demonstrated that TLR4 is over-expressed in RA synovium [31]. Investigations using animal models of inflammatory arthritis also implicate TLR4 in RA. Mice with non-functional TLR4 or mice deficient of MyD88 are protected from inflammatory arthritis [32]. As for JIA, Donn R et al. indicated that the macrophage migration inhibitory factor (MIF) have been reported to be associated with JIA [33]. And a relationship between MIF and TLR4 was found in a study of MIF-deficient mice [34], which supported the hypothesis that TLR4 is a risk factor for investigation in JIA.

The TLR4 Asp299Gly (rs4986790) is a functional allele located in the exon 3 region of TLR4 gene and was known to cause an aspartic acid to glycine replacement, which alter its extracellular domain and potentially modify its binding affinity. The strong association between TLR4 Asp299Gly polymorphism and RA disease susceptibility has been reported in a Dutch cohort [35], but not in Irish, British and Spanish populations [35-37]. And no positive results was found between TLR4 Asp299Gly and JIA in UK Caucasian and Indian [5, 38]. In our study, the frequency of Asp299Gly polymorphism in central south Chinese Han population was higher than that in other Chinese Han population populations [23, $39,40]$, but was similar with that in Caucasian populations [41-44]. And a significant association was detected between TLR4 Asp299Gly and RA in central south
Chinese Han population compared to healthy controls. To our knowledge, this is the first study that a significant association between TLR4 Asp299Gly and RA in Chinese Han population was reported. Interestingly, negative result was shown by Zheng [23] and Yuan [24]. The complex genetic ethnic specificity in Chinese Han populations might contribute to the difference.

Notable, the rs41426344 appeared to be significantly associated with both RA and JIA in central south Chinese Han population. Both rs41426344C allele and CC genotype are increased in RA cases, which was similar with the result reported by Zheng [22]. There were already evidences suggesting that the rs41426344 may act as susceptibility loci with diseases [44]. Cheng et al. suggested that rs41426344 may be a functional site, which could attenuate the LPS-induced transmembrane signaling through the alteration of post-transcriptional regulation of 3'UTR and target gene expression [41]. In addition, no significant association was found between other two 3'UTR SNPs (rs11536889 and rs7873784) and RA and JIA. Though the absence of association in these two loci was detected in our present study, we cannot exclude the possible effect of these two SNPs on RA and JIA development in other populations for genetic polymorphisms often vary between ethnic groups. Thus, replication in other populations is needed before these results can be generalized.

\section{Conclusions}

We observed significant associations between RA and JIA disease susceptibility and a TLR4 variant (rs41426344) in a set of RA and JIA patients, as well as rs4986790 in RA patients and healthy individuals in central south Chinese Han population. Our finding needs to 


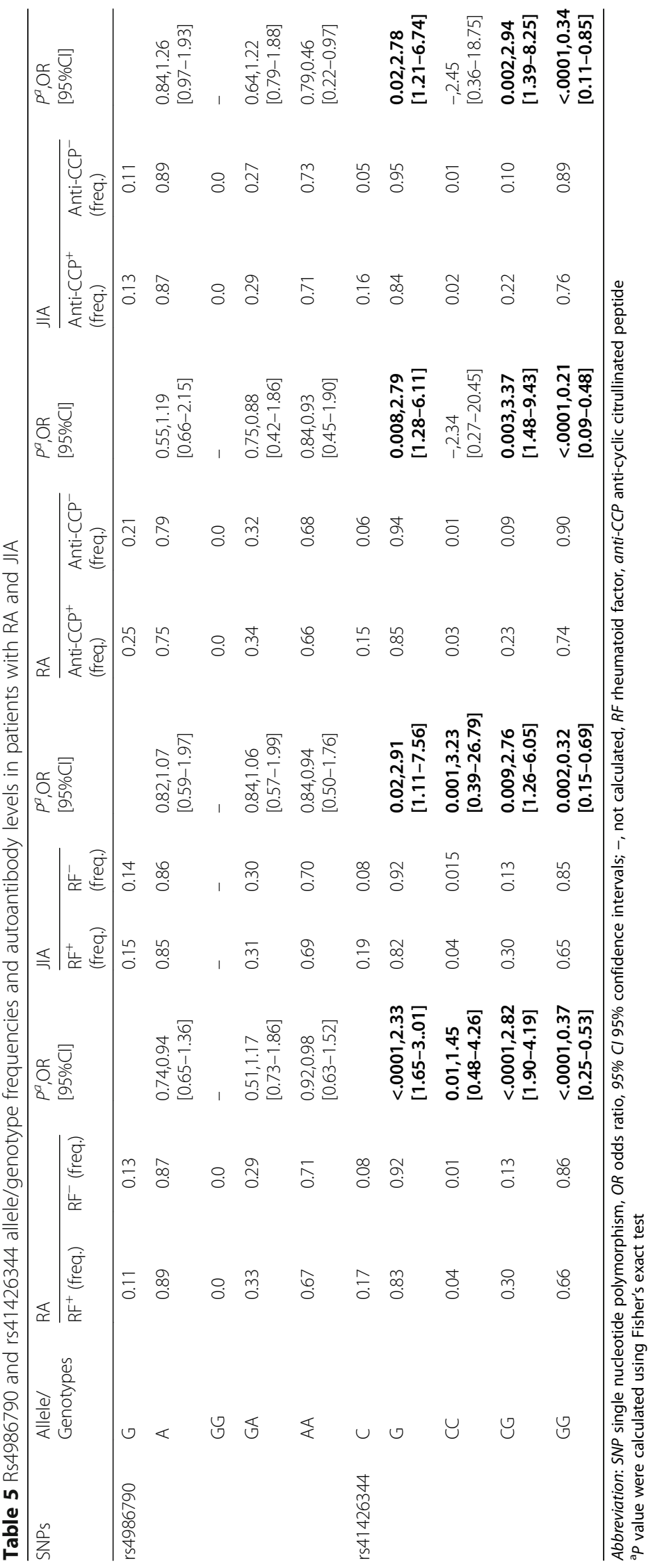


be confirmed in other larger numbers of Chinese Han population cohorts. And to identify the potential mechanisms by which variant in rs41426344 and rs4986790 affects TLR4 and RA and JIA is necessary.

\section{Additional file}

Additional file 1: Table S1. The PCR and sequencing primers of TLRA SNPs. (DOC $30 \mathrm{~kb}$ )

\section{Acknowledgements}

We are grateful to the patients and control individuals for participating in this study. In addition, we should thanks Dr. Bifeng Chen from Chinese University of Hongkong and Peter R. Patrylo, Ph. D from Departments of Physiology and Anatomy Southern Illinois University School of Medicine for Language polishing.

\section{Funding}

This study was supported in part by the Foundation of the Education Department of Hunan (11C0141, 15C0513, 16C0162), the key Foundation of the Education Department of Hunan (15A023,16A027), National Science Foundation of Hunan province (2015JJ6010), Foundation of the health department of Hunan (B2016096) and the construct program of the key discipline in Hunan province.

\section{Availability of data and materials}

All data generated or analysed during this study are included in this published article.

\section{Authors' contributions}

LT and JML designed the experiments and drafted the manuscript. YW, LHC, FL and JZ collected the samples and carried out the genotyping. MHB and JX contributed to the statistical analysis. JML and $\mathrm{HQ} L$ are project leader and planned the study. All authors read and approved the final manuscript.

\section{Competing interests}

The authors declare that they have no competing interests.

\section{Consent for publication}

Consents to publish have obtained from all subjects or their guardians.

\section{Ethics approval and consent to participate}

The study was approved by the Ethical Committee at the Changsha Medical University (EC/14/013, 06/11/2014). Written informed consents for genetic analysis were obtained from all subjects or their guardians.

\section{Author details \\ ${ }^{1}$ Department of Human Anatomy, Histology and Embryology, Institute of Neuroscience, Changsha Medical University, No. 1501 Lei Feng Road, Wangcheng District, Changsha City, Hunan Province 410219, People's Republic of China. ${ }^{2}$ School of Basic Medical Science, Changsha Medical University, Changsha, People's Republic of China. ${ }^{3}$ Experiment center for Function, Changsha Medical University, Changsha, People's Republic of China. ${ }^{4}$ Department of Neurology, Xiang-ya Hospital, Central South University, Changsha City, Hunan Province, China.}

Received: 1 November 2016 Accepted: 19 January 2017 Published online: 21 February 2017

\section{References}

1. Davidson A, Diamond B. Autoimmune diseases. N Engl J Med. 2001;345:340-50

2. Goulielmos GN, Chiaroni-Clarke RC, Dimopoulou DG, Zervou MI, Trachana M, Pratsidou-Gertsi P, Garyfallos A, Ellis JA. Association of juvenile idiopathic arthritis with PTPN22 rs2476601 is specific to females in a Greek population. Pediatr Rheumatol. 2016;14:25.

3. Kirchner M, Sonnenschein A, Schoofs S, Schmidtke P, Umlauf VN, Mannhardt-Laakmann W. Surface expression and genotypes of Toll-like receptors 2 and 4 in patients with juvenile idiopathic arthritis and systemic lupus erythematosus. Pediatr Rheumatol. 2013;11:9.

4. Malievsky VA, Viktorova TV, Danilko KV, Nazarova LS. PReS-FINAL-2113: The association of the NFKB1 gene polymorphism with systemic onset juvenile idiopathic arthritis in Russia. Pediatr Rheumatol. 2013;11 Suppl 2:125.

5. Lamb R, Zeggini E, Thomson W, Donn R. Toll-like receptor 4 gene polymorphisms and susceptibility to juvenile idiopathic arthritis. Ann Rheum Dis. 2005;64:767-9.

6. Kuuliala K, Orpana A, Leirisalo-Repo M, Kautiainen H, Hurme M, Hannonen P, Korpela M, Mo"tto"nen T, Paimela L, Puolakka K, Karjalainen A, Repo H. Polymorphism at position +896 of the toll-like receptor 4 gene interferes with rapid response to treatment in rheumatoid arthritis. Ann Rheum Dis. 2006:65:1241-3.

7. Ospelt C, Brentano F, Rengel Y, Stanczyk J, Kolling C, Tak PP, Gay RE, Gay S, Kyburz D. Overexpression of Toll-like receptors 3 and 4 in synovial tissue from patients with early rheumatoid arthritis. Toll-like receptor expression in early and longstanding arthritis. Arthritis Rheum. 2008;58:3684-92.

8. Akira S, Takeda K, Kaisho T. Toll-like receptors: critical proteins linking innate and acquired immunity. Nat Immunol. 2001;2:675-80.

9. Schröder NW, Schumann RR. Single nucleotide polymorphisms of toll-like receptors and susceptibility to infectious disease. Lancet Infect Dis. 2005;5: 156-64.

10. Candore G, Colonna-Romano G, Balistreri CR, Di CD, Grimaldi MP. Biology of longevity: role of the innate immune system. Rejuvenation Res. 2006;9:143-8.

11. Turner MW, Hamvas RM. Mannose-binding lectin: structure, function, genetics and disease associations. Rev Immunogenet. 2000;2:305-22.

12. Buraczynska M, Baranowicz-Gaszczyk I, Ksiazek A. Toll-like receptor 4 gene polymorphism and early onset of diabetic retinopathy in patients with type 2 diabetes. Hum Immunol. 2009;70:121-4.

13. Arbour NC, Lorenz E, Schutte BC, Zabner J, Kline JN. TLR4 mutations are associated with endotoxin hyporesponsiveness in humans. Nat Genet. 2000;25:187-91.

14. Hemming NV, Blanco JCG, Segal DM, Medvedev SA, Lorenz E, Arditi M, Rallabhandi VGP, Bell J, Boukhvalova MS. Analysis of TLR4 polymorphic variants: new insights into TLR4/MD-2/CD14 stoichiometry, structure, and signaling. J Immunol. 2006;177:322-32.

15. Kinane DF, Shiba H, Stathopoulou PG, Zhao H, Lappin DF, Singh A, Eskan MA, Beckers S, Waigel S, Alpert B, Knudsen TB. Gingival epithelial cells heterozygous for toll-like receptor 4 polymorphisms Asp299Gly and Thr399ile are hypo-responsive to Porphyromonas gingivalis. Genes Immun. 2006;7:190-200

16. Montes AH, Asensi V, Alvarez V, Valle E, Ocaña MG, Meana A, Carton JA, Paz J, Fierer J, Celada A. The toll-like receptor (Asp299Gly) polymorphism is a risk factor for gram-negative and haematogenous osteomyelitis. Clin Exp Immunol. 2006:143:404-13.

17. Nuolivirta K, Hurme M, Halkosalo A, Koponen P, Korpp M. Gene polymorphism of IFNG+ 874 T/A and TLR4 + 896A/G and recurrent infections and wheezing in toddlers with history of bronchiolitis. Pediatr Infect Dis J. 2009:28:1121-3.

18. Zhang K, Zhou B, Wang Y, Rao L, Zhang L. The TLR4 gene polymorphisms and susceptibility to cancer: a systematic review and meta-analysis. Eur J Cancer. 2013;49:946-54.

19. Yin YW, Li JC, Li BH. Toll-like receptor 4 gene Asp299Gly polymorphism in ischemic cerebrovascular disease: a meta-analysis. Int J Neurosci. 2014;124:252-60.

20. Xu WD, Liu SS, Pan HF, Ye DQ. Lack of association of TLR4 polymorphisms with susceptibility to rheumatoid arthritis and ankylosing spondylitis: A meta-analysis. Joint Bone Spine. 2012;79:566-9.

21. Tizaoui K, Naouali A, Kaabachi W, Hamzaoui A, Hamzaoui K. Association of Toll like receptor Asp299Gly with rheumatoid arthritis risk: A systematic review of case-control studies and meta-analysis. Pathol Res Pract. 2015;211:219-25.

22. Yang HJ, Wei CY, Li Q, Shou T, Yang Y, Xiao CJ, Yu M, Li M, Yang ZL, Zhang $J Y$, Zheng BR. Association of TLR4 gene non-missense single nucleotide polymorphisms with rheumatoid arthritis in Chinese Han population. Rheumatol Int 2013:33:1283-8.

23. Zheng BR, Li Q, Wei CY, Qin J, Shou T, Zhou R, Shao J, Yang Y, Xiao C. Lack of association of TLR4 gene Asp299Gly and Thr399lle polymorphisms with rheumatoid arthritis in Chinese Han population of Yunnan Province. Rheumatol Int. 2010;30:1249-52.

24. Yuan M, Xia J, Ma L, Xiao B, Yang Q. Lack of the toll-like receptor 4 gene polymorphisms Asp299Gly and Thr399ile in a Chinese population. Int J Neurosci. 2010;120(6):415-20. 
25. Arnett FC: The American Rheumatism Association. revised criteria for the classification of rheumatoid arthritis. Arthritis Rheum. 1987;1988(31):315-24.

26. Di PF, Ortenzi F, Tilio M, Concetti F, Napolioni V. Genomic dna extraction from whole blood stored from 15 - to 30 -years at $-20^{\circ} \mathrm{C}$ by rapid phenolchloroform protocol: a useful tool for genetic epidemiology studies. Mol Cell Probes. 2010;25:44-8.

27. Beutler B. Inferences, questions and possibilities in Toll-like receptor signalling. Nature. 2004;430:257-63.

28. Foell D, Wittkowski H, Roth J. Mechanisms of disease: a "DAMP" view of inflammatory arthritis. Nat Clin Pract Rheumatol. 2007;3:382-90.

29. Erridge C. Endogenous ligands of TLR2 and TLR4: agonists or assistants? J Leukoc Biol. 2010;87:989-99.

30. Dhaouadi T, Sfar I, Haouami Y, Abdelmoula L, Turki S, Hassine LB. Polymorphisms of toll-like receptor-4 and cd14 in systemic lupus erythematosus and rheumatoid arthritis. Biomarker Res. 2013;1:20.

31. Sanchez-Pernaute O, Filkova M, Gabucio A. Citrullination enhances the pro-inflammatory response to fibrin in rheumatoid arthritis synovial fibroblasts. Ann Rheum Dis. 2013;72:1400-6.

32. van den Berg WB, van Lent $P L$, Joosten $L A$, Abdollahi-Roodsaz $S$, Koenders MI. Amplifying elements of arthritis and joint destruction. Ann Rheum Dis. 2007;66 Suppl 3:iii45-8.

33. Donn R, Alourfi Z, Zeggini E, Lamb R, Jury F, Lunt M, the British Paediatric Rheumatology Study Group, Meazza C, De Benedetti F, Thomson W, Ray D. A functional promoter haplotype of macrophage migration inhibitory factor (MIF) is linked and associated with juvenile idiopathic arthritis. Arthritis Rheum. 2004:50:1604-10.

34. Roger T, David J, Glauser MP, Calandra T. MIF regulates innate immune responses through modulation of Toll-like receptor 4. Nature. 2001;414:920-4.

35. Kilding R, Akil M, Till S, Amos R, Winfield J, lles MM, Wilson AG. A biologically important single nucleotide polymorphism within the toll-like receptor-4 gene is not associated with rheumatoid arthritis. Clin Exp Rheumatol. 2003;21:340-2.

36. Sánchez E, Orozco G, López-Nevot MÁ, Jiménez-Alonso J, Martín J. Polymorphisms of toll-like receptor 2 and 4 genes in rheumatoid arthritis and systemic lupus erythematosus. Tissue Antigens. 2004;63:54-7.

37. Sheedy F, Marinou IL, Wilson A. The Mal/TIRAP S180L and TLR4 G299D polymorphisms are not associated with susceptibility to or severity of rheumatoid arthritis. Ann Rheum Dis. 2008:67:1328-31.

38. Myles A, Aggarwal A. Lack of association of single nucleotide polymorphisms in toll-like receptors 2 and 4 with enthesitis-related arthritis category of juvenile idiopathic arthritis in Indian population. Rheumatol Int. 2013;33:417-21.

39. Guo QS, Xia B, Jiang Y, Morre SA, Cheng L, Li J, Crusius JBA, Peña AS Polymorphisms of CD14 gene and TLR4 gene are not associated with ulcerative colitis in Chinese patients. Postgrad Med J. 2005;81:526-9.

40. Cheng L, Eng HL, Chou MH, You, Lin TM. Genetic polymorphisms of viral infection associated Toll-like receptors in Chinese population. Transl Res. 2007;150:311-8.

41. Radstake TRDJ, Franke B, Hanssen S, Netea MG, Welsing P, Barrera P, Joosten $L A B$, van Riel PLCM, van den Berg WB. The Toll-like receptor 4 Asp299Gly functional variant is associated with decreased rheumatoid arthritis disease susceptibility but does not influence disease severity and/or outcome. Arthritis Rheum. 2004;50:999-1001.

42. Adam R, Sturrock RD, Gracie JA. TLR4 mutations (Asp299Gly and Thr399lle) are not associated with ankylosing spondylitis. Ann Rheum Dis. 2006;65:1099-101.

43. Paulus SC, Hirschfeld AF, Victor RE, Brunstein J, Thomas E, Turvey SE. Common human toll-like receptor 4 polymorphisms-role in susceptibility to respiratory syncytial virus infection and functional immunological relevance. Clin Immunol. 2007:123:252-7.

44. Hishida A, Matsuo K, Goto Y, Mitsuda Y, Hiraki A. Toll-like receptor $4+$ $3725 \mathrm{G} / \mathrm{C}$ polymorphism, Helicobacter pylori seropositivity, and the risk of gastric atrophy and gastric cancer in Japanese. Helicobacter. 2009;14:47-53.

\section{Submit your next manuscript to BioMed Central and we will help you at every step:}

- We accept pre-submission inquiries

- Our selector tool helps you to find the most relevant journal

- We provide round the clock customer support

- Convenient online submission

- Thorough peer review

- Inclusion in PubMed and all major indexing services

- Maximum visibility for your research

Submit your manuscript at www.biomedcentral.com/submit
Biomed Central 